Available online at GSC Online Press Directory

GSC Biological and Pharmaceutical Sciences

e-ISSN: 2581-3250, CODEN (USA): GBPSC2

Journal homepage: https://www.gsconlinepress.com/journals/gscbps

(RESEARCH ARTICLE)

\title{
Nutrient intake of West African dwarf (WAD) goats fed cassava peels supplemented with nitrogen sources
}

\author{
Ajagbe Adekunle David *, Oyewole Benjamen Osigbodi, Aribido Samson Oluwatoyin and Oyibo Amina
}

Department of Animal Production Kogi State University, Anyigba.

Publication history: Received on 10 July 2020; revised on 15 July 2020; accepted on 17 July 2020

Article DOI: https://doi.org/10.30574/gscbps.2020.12.1.0214

\begin{abstract}
A feeding trial was carried out for 60 days with 40 growing West African Dwarf (WAD) bucks aged 5 - 7 months with an initial weight of $5.25 \mathrm{~kg} \pm 0.35$ to determine their nutrient intake. The goats were randomly allocated to five treatments, each treatment had eight replicates. Five diets were compounded CPU (100\% urea treated cassava peel). CPF (60\% untreated cassava peel, $40 \%$ cassava foliage), CPM (60\% untreated cassava peel, 40\% poultry manure), CPUF (60\% untreated cassava peel, $20 \%$ cassava foliage and 20\% treated cassava peel).CPFM (60\% untreated cassava peel, $20 \%$ cassava foliage, $20 \%$ poultry manure). Result obtained indicated that nutrient intake significantly $(\mathrm{P}<0.05)$ varied among the dietary treatments. CPU had significant $(\mathrm{P}<0.05)$ higher dry matter intake, organic matter intake, crude fibre intake and nitrogen free extract intake than other treatments while CPF had significantly $(\mathrm{P}<0.05)$ better crude protein intake than other treatments. Acid detergent fibre intake was significantly $(\mathrm{P}<0.05)$ higher in CPM $(163 . \mathrm{g} / \mathrm{d}) \mathrm{while} \mathrm{NDF}$ had significant higher value in CPFM (198.96g/day). Hemicellulose intake was significantly $(\mathrm{P}<0.05)$ higher (93.02g/day) in CPM than other treatments. The study revealed that supplementing the diets of grazing West African Dwarf goats with nitrogen sources such as urea, cassava foliage, poultry manure can boost the intake of the animals which thereby leads to better productive performance of the animals.
\end{abstract}

Keywords: WAD goats; Nutrient intake; Urea; Cassava foliage; Poultry manure

\section{Introduction}

Livestock enterprise especially small ruminants production is one of the most resourceful and reward-able ventures in agriculture all over the world. Their easy handling, adaptability to various climatic conditions, modest feed require ments and efficient conversion of limited feed resources among others favour their production both in small hold and large scale. A vibrant and innovative feed industry with capacity to utilize alternative and sustainable feed resources from agro industrial by-products and organic farm wastes can significantly boosts small ruminant production [1]. Cassava peel, one of the readily available and abundant agro industrial by-products has been fed to goats in various forms: with rumen epithelia wastes [2], with cassava foliage [3], with graded urea fertilizer [4] and with poultry manure [5]. [6] opined that the quality of protein available for the ruminants to utilize poor quality feed stuff is immaterial in their nutrition, what is paramount is the utilization of compound rich in N- supplies in combination with the fibrous feed materials. Increased $\mathrm{N}$ - supplies can improve the rumen environment in term of appropriate $\mathrm{pH}_{\text {buffer, }} \mathrm{rumen}_{\mathrm{NH}}$ concentration and metabolites for increased fermentation of the basal feedstuffs and other by-products by rumen micro-organisms [7]. Common ruminant dietary nitrogen resources exist, such as highly nitrogenous forages and faecal waste from well managed poultry litter at very low cost [8].These materials represent potential source of crude protein for ruminant animals and may serve as rational application of simple technology and skill to recycle these wastes into the animal feed industry with expectation that there would be double successes of producing animal protein profitably and alleviating pollution within our immediate environments[8]. The objective of this study was to investigate nitrogen intake of West African Dwarf goats fed nitrogen supplemented cassava peel meal.

\footnotetext{
${ }^{*}$ Corresponding author: Ajagbe Adekunle David
} 


\section{Material and methods}

The experiment was carried out at the Sheep and Goat Unit of Department of Animal Production, Kogi State, University, Anyigba, Kogi State. Anyigba is located in the derived Savannah of Nigeria between Latitude $7^{0} 15^{1}$ and $7^{0} 2^{2} \mathrm{~N}$ of the equator and Longitude $7^{0} 11^{1}$ and $7^{0} 32^{1} \mathrm{E}$ of the Greenwich meridian [9]. The wet season spreads over a minimum of seven (7) months and it extends from late April to October with the dry season spanning from November to March. The area is characterized by luxuriant growth of many tall grass species like gamba grass (Andropogon tectorium, Andropogon gayanus), elephant grass (Pennisetum purpureum), guinea grass (Panicum maximum) and some short grasses [9].

Cassava peels were collected at Fadama Cassava Processing Centre at Ojuiapata, along Ankpa Road, Kogi State, Nigeria. At the centre, simple processing methods as follows were adopted: Fresh cassava peels, free from stumps were collected and grated before being subjected to hydraulic press for dewatering. The dewatered peels were then pulverized and sieved to obtain the coarse mash, which was then sun-dried for 2-3days before being loaded into bags for feeding animals [10]. Fresh cassava foliage was harvested fresh and sundried for 2-3 days until the leaves became brittle and milled for diet compounding. Poultry manure free from wood shavings and litter materials was obtained from poultry enterprise that installed battery cage system, and sundried 4-5 days prior to milling for proportional diet combinations and mixing. Graded urea fertilizer was purchased in market. The processed cassava peel meal was treated with fertilizer grade urea by spraying $4 \%$ aqueous solution (4kg urea to every 100 litre of water) on $100 \mathrm{~kg}$ cassava peels enclosed in air tight container covered with plastic sheet and allowed for 21 days before exposure to air to let out residual $\mathrm{NH}_{3}$ gas prior to usage for diet formulation in accordance with the method adopted by [11]; [10]. The animals were allowed to graze around the university farm area between $9.00 \mathrm{am}-2.00 \mathrm{pm}$ thereafter concentrates diets were offered: The dietary combinations offered were

CPU = Cassava peel ensiled with $4 \%$ urea graded fertilizer

$\mathrm{CPF}=$ Cassava Peel + Cassava Foliage mixed meal

$\mathrm{CPM}=$ Cassava Peel + Poultry Manure mixed meal

CPUF $=$ Cassava Peel + Cassava foliage +ensiled Cassava Peel

CFPM=Cassava Peel + Cassava foliage + Poultry Manure

Rations of supplementary mixed diets were offered to the WAD goats at 3\% of body weight after about 5-6 hours grazing while water was provided ad libitum [10].

Forty growing West African Dwarf (WAD) goats of about 6-7 months old were used for the study. They were sourced from nearby goat market in the environs around Anyigba. The animals were treated against both ecto and endo parasite infestations. They were tagged and allowed fourteen days adjustment period before the commencement of the study. The animals were randomly assigned to five treatment groups consisting of eight animals, each animal serving as a replicate and housed individually in their pens, for 60 days [10]. The design was a Completely Randomized Design (CRD). Data on feed intake by individual animal was recorded daily and left over feed was weighed and subtracted from the total quantity offered to determine the daily feed intake. Average daily feed intake was obtained by dividing the total feed intake by the number of experimental days. Samples of experimental diets were collected during the experiment for proximate composition determination. The samples were weighed and dried in an oven to constant weight at 105 ${ }^{\circ} \mathrm{C}$. The dried samples were weighed and ground to pass through $2 \mathrm{~mm}$ sieve. The experimental diets were analyzed for moisture, ash, ether extract and crude fibre according to the methods of Association of Official Analytical Chemists [12], while nitrogen content was determined by the micro Kjeldahl method [12]. Nitrogen free extract was determined by difference while fibre fractions were determined using the method of [13]. 
Ajagbe et al. / GSC Biological and Pharmaceutical Sciences, 2020, 12(01), 189-195

Table 1 Feed composition of cassava peal meal enriched with supplemental nitrogen sources

\begin{tabular}{llcccc}
\hline Ingredients & CPU & CPF & CPM & CPUF & CPFM \\
\hline Urea Treated Cassava Peel & 100 & - & - & 20 & - \\
Untreated Cassava Peel & - & 60 & 60 & 60 & 60 \\
Poultry Manure & - & - & 40 & - & 20 \\
Cassava Foliage & - & 40 & - & 100 & 20 \\
Total & 100 & 100 & 100 & & 100 \\
\hline $\begin{array}{l}\text { CPU= Cassava peels + 4\% urea graded fertilizer CPF= Cassava peels + cassava foliage CPM= Cassava peels + poultry manure } \\
\text { CPUF= Cassava peels + 4\% urea graded fertilizer + cassava foliage, CPFM= Cassava peels + Cassava foliage + poultry manure. }\end{array}$
\end{tabular}

\section{Results}

Nutrient composition of experimental diets is shown in Table 2. The dry matter (DM) content of the diets ranged from 82.38 to $85.60 \%$. Organic matter (OM) content of the concentrate supplements ranged between $80.53 \%$ and $77.86 \%$. The crude protein content of the concentrate supplement ranged between $9.95 \%$ and $11.89 \%$ while the crude fibre content of the diets ranged from $9.68 \%$ to $10.95 \%$. The value of ether extract obtained in this study ranged from $2.99 \%$ to $3.25 \%$. The ash content obtained varied between $4.85 \%$ and $5.77 \%$ while the nitrogen free extract ranged from $52.59 \%$ to $56.02 \%$. The acid detergent fibre and neutral detergent fibre ranged from $15.90 \%-31.85 \%$ and $29.22 \%$ $50.01 \%$ respectively. Hemicellulose ranged from $11.42 \%-18.16 \%$.

Table 2 Proximate composition of supplementary diets (\%)

\begin{tabular}{|c|c|c|c|c|c|}
\hline Nutrients & CPU & CPF & CPM & CPUF & CPFM \\
\hline Dry matter & 85.60 & 83.23 & 83.63 & 84.40 & 85.38 \\
\hline Organic Matter & 80.05 & 77.98 & 77.86 & 79.25 & 80.53 \\
\hline Crude Protein & 9.95 & 11.89 & 11.09 & 10.70 & 10.89 \\
\hline Crude Fibre & 10.95 & 10.25 & 10.62 & 10.15 & 9.68 \\
\hline Ether Extract & 3.13 & 3.25 & 3.25 & 3.20 & 2.99 \\
\hline Ash & 5.55 & 5.25 & 5.77 & 5.15 & 4.85 \\
\hline Nitrogen Free Extract & 56.02 & 52.59 & 52.63 & 55.20 & 51.00 \\
\hline Neutral Detergent Fibre & 29.22 & 39.95 & 50.01 & 29.00 & 39.73 \\
\hline Acid Detergent Fibre & 17.80 & 26.05 & 31.85 & 15.90 & 25.23 \\
\hline Hemicellulose & 11.42 & 13.90 & 18.16 & 11.42 & 14.50 \\
\hline
\end{tabular}

\subsection{Nutrient intake (g/day) of West African Dwarf goats fed cassava peels meal enriched with supplemental nitrogen sources}

The results of nutrient intake of WAD goats fed with cassava peels enriched with supplemental nitrogen is presented in Table 3. All the parameters for nutrient intake were significantly $(\mathrm{P}<0.05)$ influenced by dietary treatments. Dry matter (DM) intake ranged from 412.53-451.26 g/day with CPU having significant $(\mathrm{P}<0.05)$ higher value. Organic matter $(O M)$ intake ranged from 480.51-497.91 g/day with CPU having the highest value. The crude protein (CP) intake ranged from 52.45-61.28 g/day with CPF having the highest value while crude fibre intake fell between 48.96 and $57.73 \mathrm{~g} /$ day, CPU had significant $(\mathrm{P}<0.05)$ highest value. Nutrient intake for ether extract, ash and nitrogen free extract ranged from15.12 to17.93g/day, 24.57-9.56 g/day and 269.59-295.32 g/day respectively. Ether extract ranged from $16.20 \mathrm{~g} /$ day-17.93g/day while ash content was between $24.56 \mathrm{~g} /$ day and $29.56 \mathrm{~g} /$ day. Nitrogen free extract intake was significantly $(\mathrm{P}<0.05)$ higher in CPU (295.32 g/day) but lower in CPM (269.64 g/day). Acid detergent fibre intake 
was significantly $(\mathrm{P}<0.05)$ higher in CPM $(163 . \mathrm{g} / \mathrm{d})$ while NDF had significant higher value in CPFM $(198.96 \mathrm{~g} / \mathrm{day})$. Hemicellulose intake was significantly $(\mathrm{P}<0.05)$ higher $(93.02 \mathrm{~g} /$ day $)$ in $\mathrm{CPM}$ than other treatments.

Table 3 Daily nutrient intake of West African dwarf goats fed cassava peel meal supplemented with nitrogen sources (g/day).

\begin{tabular}{llllllll}
\hline Parameters & CPU & CPF & CPM & CPUF & CPFM & SEM & LOS \\
\hline Dry Matter & $451.26^{\mathrm{a}}$ & $428.94^{\mathrm{b}}$ & $426.33^{\mathrm{d}}$ & $426.73^{\mathrm{c}}$ & $412.53^{\mathrm{d}}$ & 2.54 & $*$ \\
Organic Matter & $404.33^{\mathrm{a}}$ & $401.89^{\mathrm{b}}$ & $398.82^{\mathrm{c}}$ & $400.21^{\mathrm{d}}$ & $403.27^{\mathrm{c}}$ & 1.31 & $*$ \\
Crude Protein & $52.45^{\mathrm{d}}$ & $61.28^{\mathrm{a}}$ & $56.81^{\mathrm{b}}$ & $54.21^{\mathrm{d}}$ & $55.07^{\mathrm{c}}$ & 0.61 & $*$ \\
Crude Fibre & $57.73^{\mathrm{a}}$ & $52.83^{\mathrm{c}}$ & $54.38^{\mathrm{b}}$ & $51.42^{\mathrm{d}}$ & $48.96^{\mathrm{e}}$ & 0.59 & $*$ \\
Ether Extract & $16.50^{\mathrm{c}}$ & $16.75^{\mathrm{b}}$ & $17.93^{\mathrm{a}}$ & $16.20^{\mathrm{d}}$ & $16.20^{\mathrm{d}}$ & 0.18 & $*$ \\
Ash & $29.26^{\mathrm{b}}$ & $27.26^{\mathrm{c}}$ & $29.56^{\mathrm{a}}$ & $26.09^{\mathrm{d}}$ & $24.56^{\mathrm{e}}$ & 0.39 & $*$ \\
NFE & $295.32^{\mathrm{a}}$ & $271.03^{\mathrm{d}}$ & $269.58^{\mathrm{e}}$ & $279.64^{\mathrm{b}}$ & $273.12^{\mathrm{c}}$ & 1.92 & $*$ \\
ADF & $93.84^{\mathrm{d}}$ & $134.25^{\mathrm{b}}$ & $163.15^{\mathrm{a}}$ & $80.39^{\mathrm{e}}$ & $126.34^{\mathrm{b}}$ & 6.07 & $*$ \\
NDF & $154.04^{\mathrm{c}}$ & $205.88^{\mathrm{b}}$ & $225.99^{\mathrm{a}}$ & $146.62^{\mathrm{c}}$ & $198.96^{\mathrm{b}}$ & 6.67 & $*$ \\
Hemicellulose & $57.68^{\mathrm{d}}$ & $71.63^{\mathrm{c}}$ & $93.02^{\mathrm{a}}$ & $57.67^{\mathrm{d}}$ & $72.61^{\mathrm{b}}$ & 5.06 & $*$ \\
\hline
\end{tabular}

abcde - Means in the same row with different superscript are significant different $(\mathrm{P}<0.05)$. SEM- Standard Error of Mean, CPU= cassava peels $+4 \%$ urea graded fertilizer, $\mathrm{CFU}=$ cassava peels + cassava foliage, $\mathrm{CPM}=$ cassava peels + poultry manure, $\mathrm{CPUF}=$ cassava peels $+4 \%$ urea graded fertilizer + cassava foliage, $\mathrm{CPFM}=$ cassava peels + cassava foliage + poultry manure, $\mathrm{NFE}=$ Nitrogen free extract, $\mathrm{ADF}=$ Acid detergent fibre, $\mathrm{NDF}=$ Neutral detergent fibre, $\mathrm{LOS}=$ Levels of significance.

\subsection{Discussion}

\subsubsection{Nutrient composition of supplementary diets}

Dry matter contents of the diets are comparable to $83.13 \%$ - 88.21\% reported by [14] for molasses urea multi-nutrients blocks. The observed dry matter value is an indication of the shelf life of the diets. The higher the dry matter the longer the shelf life and the more resistance to the growth of mould. Organic matter content fell below $92.52 \%$ to $94.50 \%$ reported by [4] for urea treated cassava peels fed to WAD goats. The values of organic matter obtained in this study might be due to the nature of supplemental nitrogen used in this study. Crude protein (CP) contents are lower than $20.56 \%-21.61 \%$ reported by [15], but comparatively higher than $9.75 \%$ reported by [4] who fed graded levels of urea treated cassava peels to grazing WAD goats. The crude protein of the diets were generally higher than $8 \%$, below which [16] observed that feeds will not provide the required levels of ammonia for optimum rumen microbial activity. The values above $8 \%$ for crude protein obtained in this study may be attributed to the urea treatment and the inclusion of poultry manure and cassava foliage which are the sources of supplemental nitrogen in the diets. The productive crude protein obtained in this study seems adequate for productive performance in grazing goats as additional nutrients are made available in natural herbage being grazed. Crude fibre (CF) content values are lower than the values reported by [17], ether extract (EE) values are lower than 3.02 and 6.84 reported by [18]. Ash contents are lower than $8.89 \%$ $11.00 \%$ reported by[15], nitrogen free extract NFE) values are higher than values reported by[17]. Proximate composition values observed for the supplementary diets are comparable to those reported by [19]. This is an indication that the diets can be potential supplements to grazing goats as well as goats being fed other crop residues in the dry season. Apparently, the diets may assist in improving the activities of rumen microbes by generating high level of ammonia in the rumen that will promote efficient digestion process [20]. Also the fibre fraction level obtained in this study was lower than the safe upper limit of $60 \%$ reported by [21] for guaranteed forage intake by ruminant. The result of the fibre fractions obtained in this study was also lower than the value reported by [22]. The fibre fractions showed that the diets have the potentials to support intestinal movement and proper rumen function. This may imply that the fibre fractions of the diet have the potential to improve fermentation in the fore stomach of the animals. [23] stated that excess fibre fractions especially NDF reduces the rate of fermentation and feed intake, but little fibre leads to rapid rumen fermentation.

\subsubsection{Nutrient intake of WAD goats fed cassava peels supplemented with nitrogen sources}

The dry matter intake (DMI), organic matter intake (OMI), crude fibre intake (CFI) and nitrogen free extract (NFE) intake were better $(\mathrm{P}<0.05)$ in group supplemented with urea treated cassava peels $(\mathrm{CPU})$ than other treatments. The 
DM intake obtained in this study is higher than 87.1-107.8g/day reported by [24] who fed cassava peel and poultry manure to WAD goats. Higher DMI, CFI and NFE intake in the group supplemented with urea treated cassava peels (CPU) may be attributed to the urea treatment and ensiling process the cassava peels underwent. This might have degraded the cell wall content present in the cassava peels as well as making the diet more digestible, thus bringing about improved microbial degradation and maximized intake. This is indicated in the higher value of nitrogen free extract obtained for CPU. [13] opined that intake is influenced by the rate, extent of ruminal digestion, the rate of passage and microbial digestion of treated cell wall. Urea treatment of cassava peels could have increased microbial degradation and amount of digesta that moved through the stomach compartments of the animals with a consequential increased intake. This implies that nitrate can be safely used as rumen supplementary nitrogen source as well as urea to improve animal feed intake and performance with another tremendous advantage of reduction of rumen methane emission. The CPU was also observed to have less fibre fractions compared to other treatment groups. This may be due to the degradation effect of ensilation. Significantly $(\mathrm{P}<0.05)$ higher value of crude protein intake $(\mathrm{CPI})$ was observed in $\mathrm{CPF}$ than other treatments. This might be due to higher $\mathrm{CP}$ content present in cassava foliage as reported by [25]. However, the result obtained in this study is in contrast to the report of [26] who used Moringa oleifera, Gliricidia sepium and cassava foliage to feed West African Dwarf (WAD) goats. The researchers posited that the least DM intake was recorded for cassava foliage. According to [27], variations in feed and nutrient intake can be attributed to differences in breed, body weight, types of diet and length of time spent on the diet. [28] also posited that feed intake is greatly influenced by the palatability of the feed and animals' level of productivity. Therefore, the value of nutrient intake recorded in this study could be attributed to palatability and acceptability of the diet to the goats. More so, the aromatic smell of the urea treated cassava peels after fermentation might have conferred better palatability and acceptability, thereby resulting in better intake. The lower value of lignin fractions for CPU in this report could be attributed to the ensiling process adopted in treating the cassava peel and the rumen microbial degradation of the urea treated cassava peels used in this study.

\section{Conclusion}

Based on the results obtained from this study, it is concluded that supplementing the diets of grazing West African Dwarf goats with nitrogen sources such as urea, cassava foliage and poultry manure can boost the intake of the animals as well as result in better productive performance of the animals.

\section{Compliance with ethical standards}

\section{Acknowledgments}

The Authors wish to acknowledge the Management of Kogi State University Anyigba for the provision of facility at the Livestock Teaching and Research Farm that was used for the feeding trial. We are also indebted to the Technical Staff members of the Livestock Teaching and Research Farm of Kogi State University Anyigba for their kind support.

\section{Disclosure of conflict of interest}

All authors declare no conflict of interest exists.

Statement of ethical approval

The research was conducted in accordance with the ethical standard of the institution.

\section{References}

[1] Okike I, Anandan S, Lawrence K, Claude F, Joseph A, Ranajit B, Peter K, Alan D, Alabi T and Blummel M. (2015).Technical innovations for small scale producers and household to process wet cassava peels into high quality animal feed ingredients and aflasafe ${ }^{\mathrm{TM}}$ substrate. Food Chain,5(1-2).

[2] Bawala TO, Adekoke EO, Ojekunle AO, Adu IF and Aina BJ. (2007). Utilization of Cassava peel and Rumen Epithelial waste diets by West African Dwarf Sheep. Asset Series A, 7(1), 168 - 180.

[3] Ukanwoko AI and Ibeawuchi JA. (2014). Evaluation of cassava leaf meal based Milk production by the West African Dwarf goats in south eastern Nigeria. Journal of Agriculture and Veterinary Sciences, 7(8), 27-30.

[4] Uza DV, Barde RE and Ayoade JA. (2005). The Effects of urea treated cassava peels as supplements to West African Dwarf goats grazing natural pasture. Nigerian Veterinary Journal, 26(1), 1-5. 
[5] Yusuf AO, Ekunseitan DA, Bawala TO, Ayoola AA and Ogunnowo AE. (2013).Impact of broiler litter waste and urea based diets on performance of young West African Dwarf goats. The Pacific Journal of Science and Technology, 14(2), 425-432.

[6] Kalio GA, Ayuk AA and Agwunobi LN. (2014). Performance of West African Dwarf Goats fed N-Treated source and forage supplemented cassava peel in humid Cross Rivers State, Nigeria. American Journal of Experimental Agriculture, 4(6), $629-638$.

[7] Osuji PO, Fernandez-Rivera S and Odenyo A. (1995). Improving the utilization and protein supply in animal fed poor -quality roughages: ILRI Nutrition Research and Plans. In:Rumen Ecology Research Planning (EDS. Wallace, R.J. and Lahlou- Kassi, $\quad$ A.). Proceeding of a workshop held at ILRI, Addis Ababa, 1-2.

[8] Animut G, Merkel GRC, Abebe G, Sahlu T and Goetsch AL. (2002). Effects of level of broiler litter in diets containing wheat straw on performance of Alpine doelings.Small Ruminant Research, 44, 125-134.

[9] Ifatimehin 00, Musa SD and Adeyemi J0. (2006). Analysis of the changing land use and it's impact on the environment of Anyigba Town, Nigeria. Journal of Sustainable Development in Africa, 10(4), 45-50.

[10] Ajagbe DA, Aribido SO, Oyewole BO and Egwuje CO. (2019). Hematology and Serum Biochemistry of Growing West African Dwarf Goats Fed Cassava Peel with Supplemental Nitrogen Sources. Agricultural Extension Journal, 3(3), 1-6.

[11] Puck B, Arno M and Jolianne R. (2004). Dairy cattle management. Agrodok- series, (14) 23.

[12] AOAC. (2005). Official methods of analysis. $18^{\text {th }}$ ed. Association of Official Analytical Chemist, Arlington, V.A, 806842.

[13] Onwuka C FI. (1999). Molasses Blocks as supplementary feed resources for ruminants. Archivo Zootechica 48, 89 -94 .

[14] Ikyume TT, Okwori AI and Tsewua A. (2018). Nutrient utilization by West African dwarf (WAD) goats fed selected tree forages and legume. American Journal of Translation Resources, 2(1), 19-23.

[15] Norton BW. (2003). The nutritive value of tree legumes in Tropical Agriculture. Gutteridge R.G.and Shelton H.M.

[16] Ukanwoko AI, Ahamefule FO and UkaChukwu SN. (2009).Nutrient intake and digestibility of West African Dwarf bucks fed cassava peel-cassava leaf meal based diets in south eastern Nigeria. Pakistan Journal of Nutrition, 8 (7), 983-987.

[17] Gabriel OS, Fajemisin AN and Onyekachi DE. (2018) Nutrient Digestibility Nitrogen Balance and Blood Profile of West African Dwarf Goats fed cassava peels with urea -molasses multi-nutrient blocks (UMMB) supplement. Asian Research Journal of Agriculture, 9(4), 1-11.

[18] Guimaraes GS, Silva da FF, Silva da LL, Galvao LMG, Santos dos LM and Alencar AM. (2014). Intake, Digestibility and performance of lambs fed with diets containing cassava peels. Scientific Agro techonology, 38(3), 295-302.

[19] Orskov ER. (1995). Optimizing rumen environment for cellulose digestion: In Rumen Ecology Research Planning (eds. R.J. Wallace and A. Lahlou- Kassi). Proceedings of a Workshop held at ILRI, Addis Ababa, Ethiopia, 1318,177-182.

[20] Meissner HH, Viljoen MO and Van Niekerk WA. (1991). Intake and digestibility by sheep of Antherphora, Panicum Rhodes and Smooth finger grass In.Proceedings of the 1Vth International Rangeland Congress, September 1991, Montpeller, France, 648-649.

[21] Oni AO, Onwuka CF, Arigbede OM, Anele UY, Oduguwa OO, Onifade OS and Tan ZL. (2010).Chemical Composition and nutritive value of four varieties of cassava leaves grown in South-Western Nigeria. Journal of Animal Physiology and Animal Nutrition, 95(5), 583-590.

[22] Fasae OA, Amos AO, Owodunni A and Yusuf AO. (2014). performance haematological parameters and faecal egg count of semi-intensively managed West African Dwarf sheep to varying levels of cassava leaves and peels supplementation. Pertanika Tropical Journal of Agricultural Science, 38(1), 71 - 81.

[23] Adegbola AA, Smith OB and Okeudo NJ. (1990). Responses of WAD sheep fed cassava peel and poultry manure based- diets. In: Utilization of research results on forage and agricultural by- products materials as animal feed resources in Africa. Proceedings of a workshop held in Malawi 5-9 Dec.1988. B.H Dzowela, A.N Said,Astrat Wendern - Agenehu and J.A Katile (eds), PANESA/ARNAB, Adiss ababa, Ethiopia, 833-839. 
[24] Van Soest PJ and Robertson JB. (1985). Dietary fibre estimation in concentrates feedstuffs. Journal of Animal Science, 45(Supple.1) 254.

[25] Anaeto M, Sawyerr AF, Alli TR, Tayo GO, Adeyeye JA and Olarinmoye AO. (2013). Cassava Leaf Silage and Cassava Peel as Dry Season Feed for West African Dwarf Sheep Global Journal of Science Frontier Research Agriculture and Veterinary Sciences, 13(2), 1.

[26] Fadiyimu AA, Alokan JA, Fajemisin AN and Onibi GE. (2016). Feed intake, Growth performance and carcass chracteridtics of West African Dwarf sheep fed Moringa oleifera,Gliricidia sepium or cassava fodder as supplements to Panicum maximum.Journal of Experimental Agriculture International, 14(4), 1-10.

[27] Oladotun AO, Aina ABJ and Oguntona EB. (2003). Evaluation of formulated Agro Industrial water as dry season feed for sheep. Nigerian Journal of Animal Production, 30-80.

[28] Matthewman RW. (1977). A survey of small livestock production at the village level in the derived savannah and lowland forest zones of southwest Nigeria. M.Sc. Thesis, University of Readings, 174.

\section{How to cite this article}

Ajagbe AD, Oyewole BO, Aribido SO and Oyibo A. (2020). Nutrient intake of West African dwarf (WAD) goats fed cassava peels supplemented with nitrogen sources. GSC Biological and Pharmaceutical Sciences, 12(1), 189-195. 